\title{
Simultaneous demonstration of infectious pancreatic necrosis virus (IPNV) and Flavobacterium psychrophilum in paraffin- embedded specimens of rainbow trout Oncorhynchus mykiss fry by use of paired immunohistochemistry
}

\author{
Øystein Evensen ${ }^{1, *}$, Ellen Lorenzen ${ }^{2}$ \\ 'National Veterinary Institute, Department of Pathology, PO Box 8156 Dep., N-0033 Oslo, Norway \\ ${ }^{2}$ Danish Veterinary Laboratory, Hangavej 2, DK-8200 Århus N, Denmark
}

\begin{abstract}
The Gram-negative bacterium Flavobacterium psychrophilum, which is the causative agent of rainbow trout fry syndrome (RTFS), and infectious pancreatic necrosis virus (IPNV), the causative agent of infectious pancreatic necrosis (IPN), are both highly pathogenic for rainbow trout fry. Several 'persistent' cases of RTFS have been observed concomitant with IPNV. Cultivation alone might not be sufficient for evaluation of the disease situation as both pathogens can be cultivated from fish that do not show any clinical signs of disease. In such cases it may be difficult to decide which pathogen should be considered the primary cause of the mortality observed. Further, it may be difficult to cultivate the bacterium in later stages of the disease or from dead fish that have been transported without cooling. In the case of (suspected) double infections it is therefore suggested that immunohistochemistry be included as a supplementary diagnostic tool, allowing correlation of the presence of either pathogen with pathological lesions. In the present study, fry representing different stages of RTFS from 3 clinical outbreaks were shown to suffer from ongoing double infections as demonstrated by immunohistochemistry and supported by cultivation of the 2 pathogens. The general finding was that single cells of the exocrine pancreas were positive for the virus, whereas bacteria were mainly demonstrated in the interstitial tissue surrounding the pancreatic islets. In some endothelial cells of the head kidney, both pathogens were detected in the same cell. These findings as well as various protocols in relation to the methodology are discussed.
\end{abstract}

KEY WORDS: Rainbow trout fry syndrome - Flavobacterium psychrophilum - Infectious pancreatic necrosis - IPNV - Paired immunohistochemistry

Rainbow trout fry syndrome (RTFS) has caused severe mortality in rainbow trout hatcheries in Denmark and in other European countries during the past

-E-mail: oystein.evensen@vetinst.no
10 to 12 yr (Bernardet et al. 1988, Lehmann et al. 1988, Lorenzen et al. 1991، Santos et al. 1992, Sarti et al. 1992, Toranzo \& Barja 1993). The causative agent of RTFS has been demonstrated to be a Gram-negative bacterium, Flavobacterium psychrophilum [previously Cytophaga psychrophila/Flexibacter psychrophilus (Bernardet et al. 1996)] (Baudin-Laurencin et al. 1989, Evensen \& Lorenzen 1996). The same bacterium has been shown to be the pathogen involved in the previously described bacterial coldwater disease (BCWD) or peduncle disease affecting mainly coho salmon Oncorhynchus kisutch in the USA and Japan (Davis 1946, Borg 1960, Wakabayashi et al. 1991). The most susceptible fish are fry of 0.2 to $2.5 \mathrm{~g}$, among which mortality can be as high as 20 to $90 \%$. Fingerlings and larger fish may also be affected, but mortality is lower (Dalsgaard \& Hørlyck 1990, Bruno 1992, Santos et al. 1992, Lorenzen 1994).

Infectious pancreatic necrosis (IPN), which is caused by a birnavirus, infectious pancreatic necrosis virus (IPNV), also affects fry of rainbow trout, typically fish of 1 to $3 \mathrm{~g}$ (Hill 1982, Wolf 1988). When RTFS is diagnosed, other pathogens may be observed and IPNV is occasionally among them (Baudin-Laurencin et al. 1989, Lorenzen 1994). In Denmark IPNV has been demonstrated in several cases following an outbreak of RTFS and such double infections may lead to elimination of certain groups of affected fry. In many cases it has been assumed that recurrence of mortality was due to further episodes of RTFS. It is apparent that initiation of medical treatment against the bacterium in such cases would be of little value to the fry.

Diagnosis of IPN and RTFS follows cultivation of the causative agents IPNV and Flavobacterium psy- 
chrophilum, respectively. Both pathogens, however, can be cultivated from fish that do not show clinical signs of disease, and in case of concomitant infections it might be difficult to decide which of the 2 pathogens should be regarded as the primary cause of the observed mortality. Supplementary laboratory methods that provide additional information on the prevalence and the tissue and cellular localization of both pathogens are therefore of diagnostic value. It was for that purpose that an immunohistochemical method was developed.

Materials and methods. Fish: Rainbow trout fry from 3 fish farms in Denmark were included in the present studies. At all 3 farms the fish farmers had reported persistent fry mortality on several occasions. At Farms $A$ and $B$ a clinical outbreak of RTFS was followed by a clinical outbreak of IPNV, which almost lead to a total loss of the batch of fry. At Farm $\mathrm{C}$ only a clinical outbreak of IPN was reported, but bacteriological examination revealed that the fry also suffered from infection with Flavobacterium psychrophilum.

Bacteriological examination: Spleen and kidney material from 10 fish from the same batch of fry as that used for sampling of fish for immunohistochemical studies was inoculated onto Cytophaga agar (AOAE) and blood agar in parallel, and yellow pigmented bacteria were identified as previously described (Evensen \& Lorenzen 1996).

Virological examination: Virological examination and virus identification was performed as described by Vestergaard Jørgensen (1974). Briefly, tissue material from spleen, head kidney, and brain was homogenized and inoculated onto BF-2 cell cultures. When total cytopathic effect (CPE) was observed, virus identification was performed by neutralization. For Farms A and $\mathrm{B}, 10$ fry were pooled for one sample, whereas fry from Farm C (10 fish) were examined individually by titration.

Fixation of tissue samples: The fry were killed by an incision in the spinal cord, the abdomen was opened, and the whole fish were immediately submerged into excessive volumes of $10 \%$ phosphate buffered formaIin ( $\mathrm{pH} 7.2$ to 7.4 ) for at least 24 h at $4^{\circ} \mathrm{C}$. The fixed fish were embedded in paraffin according to standard procedures, and sections of 2 to $3 \mu \mathrm{m}$ were cut and placed on either gelatine-coated slides for immunohistochemistry or on non-coated slides for H\&E staining for morphological evaluation. Ten fry from each of the 3 farms were sampled.

Immunesera: From rabbit antiserum anti-Th raised against Flavobacterium psychrophilum strain 911209-1, which has been described elsewhere (Evensen \& Lorenzen 1996), protein A purified IgG was used. Protein A purified IgG from antiserum (K52-53-54 11.02.88) raised against a Danish isolate of IPNV serotype $\mathrm{Sp}$ and protein A purified IgG from pre-immune serum were kindly provided by Dr N. J. Olesen (Danish Veterinary Laboratory, Arhus) Non-purified rabbit antiserum (F51 22.02.96) against the same isolate of IPNV serotype $\mathrm{Sp}$ and non-purified pre-immune serum were also included in the study. Immuneserum (IV-27) with an ELISA titre against $F$. psychrophilum strain 911209-1 of 40000 was collected from an adult rainbow trout $(2$ to $3 \mathrm{~kg}$ ) which originated from a fish farm with a long history of RTFS. The serum NL-20 was collected from a rainbow trout with no known previous exposure to F. psychrophilum, and its ELISA titre was less than 40 (Evensen \& Lorenzen 1996).

Monoclonal antibodies (MAbs): MAbs 4C10 against rainbow trout IgM heavy chain were kindly provided by Dr A. Thuvander (see Thuvander et al. 1990). MAbs anti-VP2 (N1H8) against IPNV serotype Sp were kindly provided by Dr K. E. Christie (see Christie et al. 1990). MAbs IP5B11 against the N-protein of VHSV were kindly supplied by Dr N. Lorenzen (Danish Veterinary Laboratory, Århus).

Immunohistochemistry: For immunohistochemistry the techniques previously described (Evensen \& Lorenzen 1996) were followed. Incubations were performed at room temperature in a humid chamber unless otherwise stated. Three different protocols for paired staining were followed: Protocols 1 and 2 for immunoenzyme staining were done by sequential incubations, whereas Protocol 3 for immunofluorescence staining was performed by simultaneous incubation.

Protocol 1-Rabbit anti-Flavobacterium psychrophilum and MAb anti-IPNV, immunoenzyme staining: The first sequence included protein A purified anti-F. psychrophilum $(1: 100,1 \mathrm{~h})$ followed by biotinylated swine anti-rabbit IgG (DAKO, 1:300, $30 \mathrm{~min}$ ) and avidin-biotin-peroxidase (ABC-PO, Vector, $45 \mathrm{~min}$ ) diluted according to the manufacturers instructions. The reaction was developed by incubation (15 min) with AEC (3-amino-9-ethylcarbazole, $0.27 \mathrm{~g} \mathrm{l}^{-1}$, Sigma) dissolved in $\mathrm{N}, \mathrm{N}$-dimethylformamide $\left(67 \mathrm{ml} \mathrm{l^{-1 }}\right)$ in $0.1 \mathrm{M}$ acetate buffer, pH 5.2, supplied with $0.03 \%$ $\mathrm{H}_{2} \mathrm{O}_{2}$. The second sequence included MAb N1H8 against VP-2 of serotype Sp $\left(1: 50\right.$, overnight, $\left.4^{\circ} \mathrm{C}\right)$ and goat anti-mouse IgG (DAKO, 1:25, 1 h) followed by soluble complexes of alkaline phosphatase and antialkaline phosphatase (APAAP, DAKO, 1:50, $30 \mathrm{~min}$ ). Fast Red was used as substrate $\left(20 \mathrm{~min}, 1 \mathrm{~g} \mathrm{l}^{-1}\right)$ in $0.1 \mathrm{~m}$ Tris-HCl buffer, pH 8.2, supplied with naphthol AS-MX phosphate $\left(0.2 \mathrm{~g} \mathrm{I}^{-1}\right.$, Sigma), N,N-dimethylformamide (20 $\mathrm{ml} \mathrm{l}^{-1}$, Sigma) and $1 \mathrm{mM}$ levamisole (Sigma), which is an inhibitor of endogenous alkaline phosphatase. Sections were counterstained with Mayer's hematoxylin for $2 \mathrm{~min}$, and cover slips were placed over the sections using an aqueous medium (Aquamount) 
Protocol 2-Rabbit anti-IPNV and trout anti-Flavobacterium psychrophilum, immunoenzyme staining: The first sequence included protein A purified rabbit anti-IPNV serotype Sp (1:5000, overnight, $\left.4^{\circ} \mathrm{C}\right)$ followed by biotinylated swine anti-rabbit IgG, and the reaction was developed with $\mathrm{ABC}-\mathrm{PO}$ and $\mathrm{AEC}$. For the second sequence, trout hyperimmune serum IV-27 (1:5000) was incubated overnight at $4{ }^{\circ} \mathrm{C}$ followed by $1 \mathrm{~h}$ incubation with MAb $4 \mathrm{C} 10$ (1:50). Subsequently the sections were incubated with goat anti-mouse IgG followed by APAAP and developed with Fast Blue (10 min). Fast Blue BB salt (1 $\mathrm{g} \mathrm{l}^{-1}$, Sigma) was dissolved in $0.1 \mathrm{M}$ Tris- $\mathrm{HCl}, \mathrm{pH} 9.0$, supplied with naphthol AS phosphate $\left(0.1 \mathrm{~g} \mathrm{l}^{-1}\right.$. Sigma) and with $1 \mathrm{mM}$ levamisole as inhibitor. Cover slips were placed over the sections using an aqueous medium, without prior counterstaining.

Protocol 3-Rabbit anti-IPNV (F51) and trout antiFlavobacterium psychrophilum, immunofluorescence staining: Trout hyperimmune serum IV-27 (1:500) was incubated overnight at $4^{\circ} \mathrm{C}$ followed by $1 \mathrm{~h}$ simultaneous incubation with Mab 4C10 (1:50) and rabbit antiIPNV Sp (F51) 1:50. Subsequently fluorescein isothiocyanate isomer 1 (FITC) conjugated goat anti-mouse IgG (F479, DAKO) and tetramethylrhodamine isothiocyanate isomer R (TRITC) conjugated swine antirabbit IgG (R156, DAKO) were incubated (1:50) for $1 \mathrm{~h}$. Cover slips were placed over the sections using PBS: glycerol 1:9 and the sections examined with a fluorescence microscope (Leitz DMRB Das Mikroskop) equipped with a combined filter unit for FITC and TRITC (G/R 513803), and $\mathrm{a} \times 50$ and $\mathrm{a} \times 100$ water objective.

Controls were performed by rendering the first and/or the second sequence incomplete by use of nonimmune serum (trout serum NL-20), pre-immune serum (non-purified or protein A purified rabbit IgG) or a heterologous MAb (anti-VHSV N-protein, IP5B11) as substitutes for one or both of the primary reagents. The concentrations were the same as used for the trout hyperimmune serum, the non-purified rabbit antisera, the protein A purified rabbit antisera, and the homologous MAbs.

Results. Bacterial isolation: Flavobacterium psychrophilum was isolated from all fish sampled from Farms A and B and no other pathogenic bacteria were demonstrated. From Farm C, F. psychrophilum was only isolated from 4 out of 10 fry and fewer bacterial colonies were obtained by cultivation from each fish compared to Farms A and B.

Virus isolation: By virological examination IPNV serotype $\mathrm{Sp}$ was isolated from the pools of fry sampled from Farms A and B as well as from the 10 individual fish sampled from Farm $C$. The average virus titre of the fry from farm C was $7.9 \times 10^{7} \mathrm{TCID}_{50} \mathrm{ml}^{-1}$ homo- genate (starting dilution 1:10). No other viruses were demonstrated

Clinical signs/gross pathology: The fry sampled from the 3 farms showed similar clinical signs and gross pathological changes in accordance with a progressive IPNV infection. The fish were lethargic, hung at the water's surface, had poor appetite and showed 'corkscrew' swimming movements prior to death. Dark coloration of the skin, exophthalmia and a pronounced distension of the abdomen were also typical findings. The stomach was filled with a thin mucoid fluid and viscera and gills were pale.

Light microscopic and immunohistochemical findings: In fry sampled at Farms $\mathrm{A}$ and $\mathrm{B}$ as well as at Farm C, visualization of Flavobacterium psychrophilum and degenerative changes were as described recently (Evensen \& Lorenzen 1996). The fry showed typical signs of a $F$. psychrophilum septicaemia, with bacteria demonstrated in most tissues and typically involving the monocyte-macrophage system. Focal necrosis was observed in the kidney interstitium and in the spleen. The parenchyma of the latter was disorganized with loss of the normal dense appearance. In the kidney, eosinophilic degenerated tubule cells were prominent. In addition to the changes described above, single cell necrosis and focal to diffuse necrosis was demonstrated in the exocrine pancreas in the present study. Sloughing of the intestinal epithelial cells was also a typical finding. By paired immunohistochemistry, a strong staining for IPNV was revealed in areas of necrosis in the exocrine pancreas adjacent to areas of reactions for F. psychrophilum (Fig. 1). Similarly, positive immunostaining for IPNV and F. psychrophilum was demonstrated in adjacent, closely apposed cells of the interstitium in the head kidney (Fig. 2). In endothelial cells of the mid kidney, IPNV and F. psychrophilum were possibly identified in the same cell (Fig. 3). The general pattern was such that single cells of the exocrine pancreas were positive for the virus while the bacteria/bacterial products were mainly confined to the interstitial tissues, a tendency which can be seen in Fig. 1. Controls were negative for either or for both pathogens.

Discussion. The present study showed that IPNV and Flavobacterium psychrophilum could be detected simultaneously by immunohistochemistry in formalin fixed, paraffin-embedded tissue material from infected fry of rainbow trout.

Both pathogens can usually be demonstrated by cultivation, and generally the sensitivity of immunohistochemistry is considered to be lower than that of cultivation, one important factor being the influence of the fixative (Evensen \& Olesen in press). There are several additional factors that will influence the result of cultivation and immunohistochemistry. F. psychrophilum 


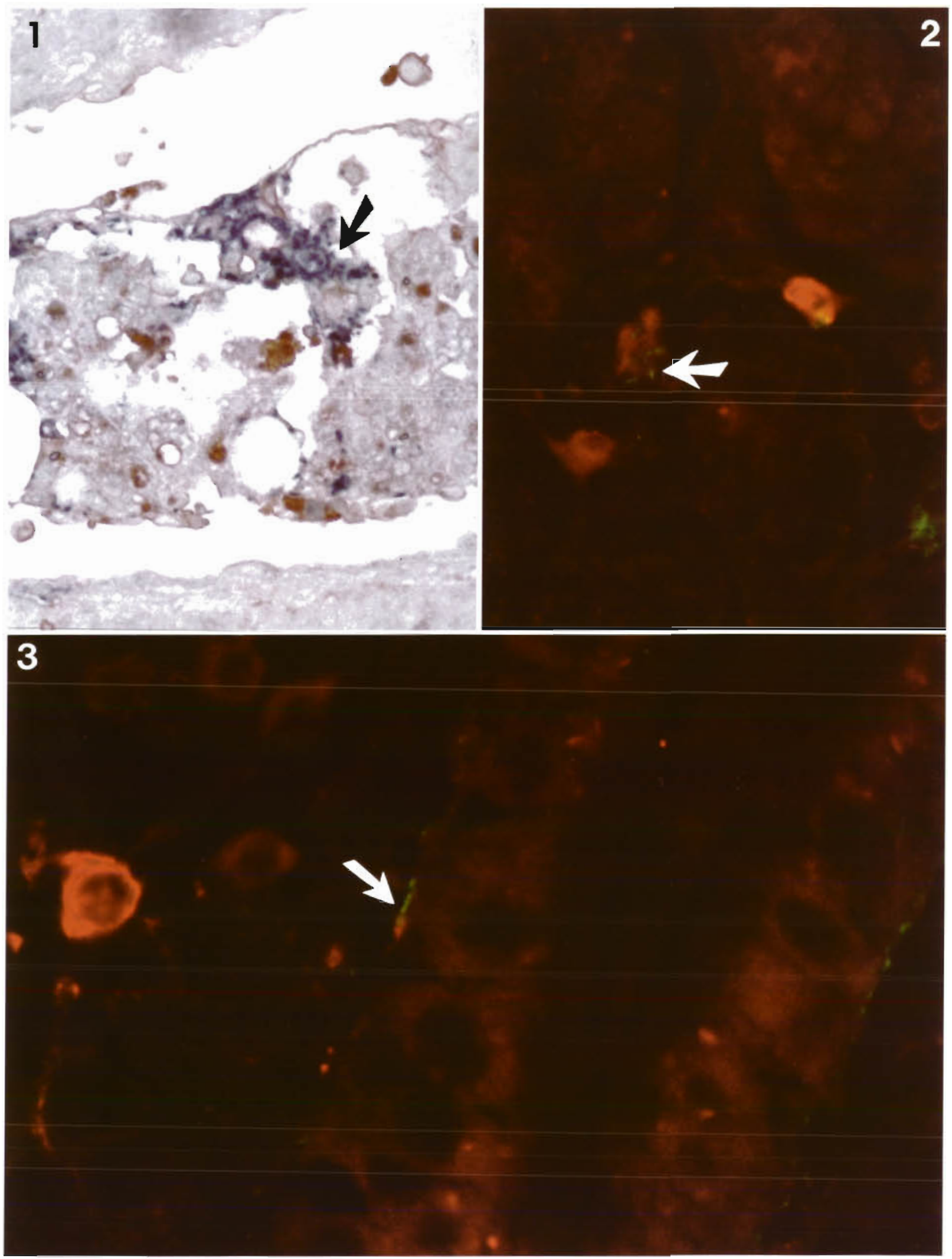


or remnants of the bacterium can apparently reside intracellularly in phagocytic cells of fish that have recovered from an infection, and in such cases cultivation may be negative while there is still a positive reaction by immunohistochemistry (Evensen \& Lorenzen 1996). Likewise, if fish or samples have been submitted to the laboratory without proper cooling, it may no longer be possible to demonstrate the bacteria by cultivation, although they can still be detected by immunohistochemical methods (Lorenzen \& Karas 1992). With IPNV, no detailed studies so far have delt with comparison between virus titre and identification by immunohistochemistry in a controlled experiment, but a recent study on VHSV/epidemiological sensitivity (Evensen \& Olesen in press) has shown that very few samples were found positive by immunohistochemistry at virus titres below $10^{4} \mathrm{TCID}_{50} \mathrm{ml}^{-1}$ (starting dilution $1: 10)$. However, the phenomenon of defective interfering (DI) particles is well known for IPNV (Nicholson \& Dexter 1975). This might result in higher sensitivity of immunohistochemistry compared to cultivation in the case of high virus titres, supposing that DI particles can be detected by immunohistochemistry. The sensitivity of either method should be considered thoroughly while evaluating the particular case in question and the importance of the pathogens

Disease susceptibility in rainbow trout to both pathogens decreases with age (Reno et al. 1978, Wolf 1988). Both IPNV and Flavobacterium psychrophilum can be isolated from fish that may have recovered from an infection. Several fish species can be infected with IPNV without being diseased (Hill 1982). Therefore, it can be difficult to evaluate the actual contribution of the isolated pathogens in the disease process, unless the material is carefully titrated, assuming high virus titres or high bacterial numbers are correlated with an ongoing infection. With use of immunohistochemistry it is possible to correlate the presence of the pathogen(s) with pathological lesions, which might make it easier to determine if one or the other or both pathogens are the causative agents in relation to mortality. In the present study, positive staining for IPNV as well as for F. psychrophilum generally correlated well with pathological lesions. Positive staining for IPNV was typically demonstrated in cells of the exocrine pancreas in close proximity to characteristic necrosis, as described previously (Evensen \& Rimstad 1990). Apparently, areas with severe necrosis did not harbour excessive amounts of virus and were usually not positive by immunohistochemistry. This is in accordance with the observations of Zwillenberg et al. (1965) studying viral haemorrhagic septicaemia (VHSV) virus using electron microscopy (EM). They were not able to find VHSV in severely necrotic tissue from naturally infected fish, and found that, in infected cell cultures, only cells showing few signs of degeneration contained the virus, whereas necrotic cells did not. As there was a relatively pronounced staining for IPNV in cells of the exocrine pancreas of most fish included in the present study, the IPNV infection should be considered as being in an acute stage. F. psychrophilum was detected interstitially and intracellularly in phagocytic cells in most tissues, and associated with necroses in the spleen and the kidney. Evensen \& Lorenzen (1996) demonstrated that the phagocytic system of the fish rapidly took up the bacteria following an experimental infection, and in chronically infected fish bacteria resided intracellularly in phagocytic cells. As many individual bacteria were demonstrated extracellularly in the present study, the F. psychrophilum infection would be considered as being in an acute to subacute phase. Thus in the present cases (Farms A, B and C), both pathogens, isolated and immunohistochemically demonstrated, would be considered the causative agents. Initiation of medical treatment against the bacterium would be of little value to the fry and only detrimental to the environment, as virus-infected fry generally have poor appetite.

In conclusion, the immunohistochemical technique described is as rapid as cultivation and, taking both the advantages and disadvantages of either method into account, it seems reasonable that immunohistochemistry can serve as a supplementary diagnostic tool. Using the paired staining technique is a novel diagnostic approach, and, although not a replacement for cultivation, it can give some additional and valuable

Figs. 1 to 3 . Tissue sections from Oncorhynchus mykiss fry simultaneously infected with Flavobacterium psychrophilum and infectious pancreatic necrosis virus (IPNV). Fig. 1. Tissue section from exocrine pancreas Farm A. Paired immunohistochemistry shows blue reaction (trout hyperimmune seruñ IV27. APAAP and Fast Blue BB) for F. psychrophilum and red-brown (rabbit anti-IPNV, ABC-PO and AEC) for IPN virus. Note single bacteria (arrow). No counterstaining. $\times 530$. Fig. 2 . Tissue section from head kidney, Farm C. Paired imunofluorescence staining shows red fluorescence [rabbit anti-IPNV (F51) and TRITC] for IPN virus in the cytoplasm of intersitital cells. Green fluorescence (trout hyperimmune serum IV27 and FITC) shows single bacteria (arrow). Note cluster of bacteria at lower right. No counterstaining. $\times 660$. Fig. 3. Tissue section from kidney (mid part), Farm B. Paired immunofluorescence shows IPN virus in the cytoplasm of interstitial cell. Endothelial cells lining tubulus show positive staining for both IPN virus and F. psychrophilum possibly in the same cell (arrow). Bacterial fragments are found in endothelial cells on the other side of the tubulus (green particulate staining). $\times 833$ 
information concerning the (mutual) importance of the pathogen(s) which may have been isolated. Therefore, it might also be an appropriate technique for pathogenesis studies including more than 1 pathogen.

\section{LITERATURE CITED}

Baudin-Laurencin F, Castric JC, Vigneulle $M$, Tjxerant $G$ (1989) La Myxobactériose viscérale de la truite arc-en-ciel Salmo gairdneri R: une forme nouvelle de la maladie de l'eau froide à Cytophaga psychrophila. Bull Acad Vét Fr 62:147-157

Bernardet JF, Baudin-Laurencin F, Tixerant G (1988) First identification of 'Cytophaga psychrophila' in France. Bull Eur Assoc Fish Pathol 8:104-105

Bernardet JF, Segers $P$, Vancanneyt $M$, Berthe F, Kersters $K$, Vandamme P (1996) Cutting a gordian knot: emended classification and description of the genus Flavobacterium, emended description of the family Flavobacteriaceae, and proposal of Flavobacterium hydatis nom.nov. (basonym, Cytophaga aquatilis Strohl and Tait 1978). Int J Syst Bacteriol 46:128-148

Borg AF (1960) Studies on myxobacteria associated with diseases in salmonid fishes. J Wildl Dis 8:1-85

Bruno DW (1992) Cytophaga psychrophila ('Flexibacter psychrophilus') histopathology associated with mortalities among farmed rainbow trout, Oncorhynchus mykiss Walbaum, in the UK. Bull Eur Assoc Fish Pathol 12:215-216

Christie KE, Ness S, Djupvik HO (1990) Infectious pancreatic necrosis virus in Norway: partial serotyping by monoclonal antibodies. J Fish Dis 13:323-327

Dalsgaard I, Hørlyck V (1990) Koldtvandssyge eller vintersår hos orreder [Coldwater disease in rainbow trout]. Ferskvandsfiskeribladet 78(4):118-120

Davis HS (1946) Care and diseases of trout. US Fish and Wildlife Service, US Dept of the Interior, US Government Printing Office, 1947, Research Report no. 12:63-66 (not available, cited in Bullock GL, Conroy DA, Snieszko SF (1971) Myxobacterioses]. In: Snieszko SF, Axelrod HR (eds) Diseases of fishes. T.F.H. Publications, Jersey City, NJ, p 60-88

Evensen $\varnothing$, Lorenzen E (1996) An immunohistochemical study of Flexibacter psychrophilus infection in experimentally and naturally infected rainbow trout (Oncorhynchus mykiss) fry. Dis Aquat Org 25:53-61

Evensen $\varnothing$, Olesen $\mathrm{NJ}$ (in press) Immunohistochemical detection of VHS virus in paraffin-embedded specimens of rainbow trout (Oncorhynchus mykiss): the influence of primary antibody, fixative, and antigen unmasking on method sensitivity. Vet Pathol

Evensen $\varnothing$, Rimstad E (1990) Immunohistochemical identification of infectious pancreatic necrosis virus in paraffin

Responsible Subject Editor: D. Bruno, Aberdeen, Scotland, UK embedded tissue of Atlantic salmon (Salmo salar). J Vet Diagn Invest 2:288-293

Hill BJ (1982) Infectious pancreatic necrosis virus and its virulence. In: Roberts RJ (ed) Microbial diseases of fish. Academic Press, London, p 91-114

Lehmann J, Mock D. Stürenberg FJ (1988) Zur Ausbreitung der bakteriellen Kaltwasserkrankheit (BKK) in NordrheinWestfalen. Fischer und Teichwirt 7:206-207

Lorenzen E (1994) Studies on Flexibacter psychrophilus in relation to rainbow trout fry syndrome (RTFS). PhD thesis, Royal Veterinary and Agricultural University, Copenhagen

Lorenzen E, Dalsgaard I, From J, Hansen EM, Herlyck V. Korsholm H, Mellergaard S, Olesen NJ (1991) Preliminary investigations of fry mortality syndrome in rainbow trout. Bull Eur Assoc Fish Pathol 11:77-79

Lorenzen E, Karas N (1992) Detection of Flexibacter psychrophilus by immunoflourescence in fish suffering from fry mortality syndrome: a rapid diagnostic method. Dis Aquat Org 13:231-234

Nicholson B, Dexter R (1975) Possible interference in the isolation of IPN virus from carrier Fish. J Fish Res Board Can 32:1437-1439

Reno PW, Darley S, Savan M (1978) Infectious pancreatic necrosis: experinental induction of a carrier state in trout. J Fish Res Board Can 35:1451-1456

Santos Y, Huntly PJ, Turnbull A, Hastings TS (1992) Isolation of Cytophaga psychrophila (Flexibacter psychrophilus) in association with rainbow trout mortality in the United Kingdom. Bull Eur Assoc Fish Pathol 12:209-210

Sarti M. Giorgetti G, Manfrin A (1992) Method for the rapid diagnosis of visceral myxobacteriosis in reared trout in Italy. Bull Eur Assoc Fish Pathol 12:53

Thuvander A, Fossum C, Lorenzen N (1990) Monoclonal antibodies to salmonid immunoglobulin: characterization and applicability in immunoassays. Dev Comp Immunol 14 415-423

Toranzo AE, Barja JL (1993) Fry mortality syndrome (FMS) in Spain. Isolation of the causative bacterium Flexibacter psychrophilus. Bull Eur Assoc Fish Pathol 13:30-32

Vestergaard Jorgensen PE (1974) A study of viral diseases in Danish rainbow trout, their diagnosis and control. Dr Vet thesis, Royal Veterinary and Agricultural University, Copenhagen, p 33-49

Wakabayashi H, Horiuchi M, Bunya T, Hoshiai G (1991) Outbreaks of cold-water disease in coho salmon in Japan. Fish Pathol (Gyobyo Kenkyu) 26:211-212

Wolf K (1988) Infectious pancreas necrosis. In: Fish viruses and fish viral diseases. Comstock Publishing Associates, Cornell University Press, Ithaca, NY, p 115-157

Zwillenberg LO, Jensen MH, Zwillenberg HL (1965) Electron microscopy of the virus of viral haemorrhagic septicaemia of rainbow trout (Egtved virus). Arch Ges Virusforsch 17 : $1-19$

Manuscript first received: November 19, 1996

Revised version accepted: April 10, 1997 